\title{
Review
}

\section{The dangerous class: The concept of the lumpenproletariat}

\author{
Clyde W. Barrow, \\ University of Michigan Press, Ann Arbor, 2020, xii+196pp., \\ ISBN: 978-0472132249
}

Contemporary Political Theory (2022) 21, S71-S75. https://doi.org/10.1057/s41296021-00487-9; published online 6 April 2021

An oft-cited description of the lumpenproletariat comes from Marx's The Eighteenth Brumaire of Louis Bonaparte. The Parisian lumpenproletariat that Louis Bonaparte recruited during the French class struggles of 1848-1851 in order to defeat the proletariat and ultimately to seize state power consisted of the following:

Alongside decayed roués with dubious means of subsistence and of dubious origin, alongside ruined and adventurous offshoots of the bourgeoisie, were vagabonds, discharged soldiers, discharged jailbirds, escaped galley slaves, swindlers, mountebanks, lazzaroni, pickpockets, tricksters, gamblers, maquereaus, brothel keepers, porters, literati, organ grinders, ragpickers, knife grinders, tinkers, beggars - in short, the whole indefinite, disintegrated mass, thrown hither and thither, which the French call la bohème (1963: 75).

As self-interested hustlers whose services are for sale to the highest bidder, the lumpenproletariat - a term Marx and Engels created - is typically co-opted, as Bonaparte demonstrates, by reactionary movements. However, Marx's taxonomy indicates the difficulty of locating a synthesized and explanatory definition for a term presented here as an 'indefinite' alterity with no clear framework of composition. The term has seemed, to some commentators, incoherent or reflective of scorn toward the disreputable or poor (Bussard, 1987; Draper, 1972; Hardt and Negri, 2004). Others - typically literary and cultural critics (Stallybrass, 1990; Mills, 2017) - have approached it as the discursive trace of a complex social scene that escapes full schematization by class relations.

Clyde W. Barrow's The Dangerous Class endeavors to restore the term to the status of a definitive concept. While most explications of the lumpenproletariat extrapolate from political writings - texts like The Eighteenth Brumaire or The Communist Manifesto - Barrow prioritizes economic works like Capital and Engels's The Condition of the Working Class in England. This lets him move past

(c) 2021 The Author(s), under exclusive licence to Springer Nature Limited. 1470-8914 Contemporary Political Theory Vol. 21, S2, S71-S75 www.palgrave.com/journals 
Marx's historically-contingent enumerations of lumpenproletarian types and insistences on their retrograde political tendencies, and to reorient the lumpenproletariat in structural terms. For Barrow, the term is defined primarily 'by its nonrelation to economic production and by its position outside capitalist relations of production' (p. 15). Rather than the non-structured social heterogeneity of Marx's Eighteenth Brumaire catalogue, it signifies a displaced segment of the proletariat that, in the present, prompts investigation into the shifting composition and political capacities of the proletariat in a postindustrial era.

Barrow presents Marx's discussion, in Capital, of the relative surplus population of former and occasional workers as defining the lumpenproletariat in economic terms. Within the surplus population, Barrow argues that Marx distinguishes between an 'honest lumpenproletariat' of workers with irregular relations to production, and the 'lowest sediment': the perpetually unemployed and what Barrow calls the 'dispossessed'. The dispossessed include the elderly, persons physically unable to work, and others lacking any role in economic production, including types typically associated with narrower definitions of the lumpenproletariat, such as criminals and vagabonds (p. 48). As capitalist accumulation develops through the consolidation and centralization of production, more workers are cast into precarious and permanent exteriority. The lumpenproletariat is thus a crucial reference point for analyzing the historical variability of working-class formation and anti-capitalist class struggle.

Barrow traces an intellectual history of such analyses. In Frantz Fanon's The Wretched of the Earth (1961), the lumpenproletariat of the colony, as ex-peasants displaced by the introduction of capitalist relations of production in agriculture, carry the kernel of the peasantry's anti-colonial culture to the cities, where they play a crucial role in the emerging revolutionary nationalist movement. In the United States in the 1960s-1970s, the Black Panther Party postulated that the African American lumpenproletariat could, because of the racial and economic histories of American capitalism, be organized as a revolutionary agent. Barrow here focuses on the oftneglected theoretical analyses of Panther leader Eldridge Cleaver. Cleaver theorized how African American workers, who suffer the brunt of economic disenfranchisement from increased automation, fill the ranks of a lumpenproletariat radically opposed to the racial and economic forces that produced its marginalization, becoming the vanguard of the proletarian negation of capitalism. Barrow positions Cleaver in his rightful place as a major thinker of race and postindustrial capitalism, and thereby contributes to the recognition and recovery of the Panthers as the most significant U.S. interlocutors in postwar Marxism.

Barrow's study closes with the work of André Gorz, Claus Offe, Jürgen Habermas, and others. After clarifying these post-Marxist interventions as expansions of, rather than departures from, the evolving body of Marxist thought, Barrow makes a case for the contemporary relevance of the lumpenproletariat's signature implication - the problem of economic nonrelationality - by outlining 
post-Marxist analyses of possible transitions from postindustrial capitalism to socialism. At stake is whether, or how, an expanding surplus population, combined with the rise of identity-based political movements articulated apart from relations of production or distribution, would lead to the eclipse of capitalism. The lumpenproletariat, Barrow thus shows, usefully orients Marxism toward the particular economic and political challenges of the present.

The visibility of those challenges has been amplified, Barrow argues, by the presidency of Donald Trump. Barrow writes that Trump followed the 'script' (p. 147) of Bonaparte's strategy in The Eighteenth Brumaire, co-opting economicallymarginalized segments of the population and bribing them with ideological reinclusion through a mix of nativism, white supremacy, and misogyny. Trump advanced the material interests of the bourgeoisie while using a lumpenproletariat clad in MAGA hats and ICE uniforms to enforce his rule. As Barrow points out, political commentators have described Trump's supporters as a white lumpenproletariat or, in Jonah Goldberg's term, a 'Trumpen Proletariat' (p. 13). But Barrow, by grounding the term within materialist examinations of the decomposition of the industrial working class, offers a more sophisticated hypothesis of how capitalist development and crisis led to the emergence of Trumpism as a particular mode of U.S. postindustrial Bonapartism.

Barrow provides a wide-ranging overview of the lumpenproletariat's appearances in Marx's and Engels's work, discussing not only familiar texts but also speeches, letters, articles, and other lesser-known writings. This thoroughness means The Dangerous Class is a much-needed resource and will be a crucial touchstone for future scholarship on the lumpenproletariat. Barrow's primary intervention is to argue that the relative surplus population encompasses internal gradations of a lumpenproletariat whose connection to the working proletariat is 'fluid and constantly shifting' (p. 42). Here he primarily argues against Hal Draper, whose influential 1972 essay reads the lumpenproletariat as a criminal parasitic demographic which is distinct from both the proletariat and surplus population. Marx, in Capital, distinguishes actively nonworking and economically-inessential 'vagabonds, criminals, prostitutes, in short the actual lumpenproletariat' (1977, p. 797) from the surplus population, which even in its lowest levels is dialectically imbricated with capitalist development. Barrow apparently excises this qualification from his reading, thus foregoing a potential investigation of how criminality might be understood in objective economic terms of class formation. Still, Barrow is able to adduce textual evidence that one of Marx's and Engels's multiple inconsistencies in describing the lumpenproletariat was, as often as not, to use it to encompass a much larger range of socioeconomically exteriorized persons than merely those engaged in morally-wayward (by Victorian standards) or illicit practices.

However, one might question the extent to which the lumpenproletariat illuminates the appeal of Trump. When Trump supporters launched their own coup of sorts on 6 January 2021, it diverged from Bonaparte's script. Writing in The Atlantic, Adam Serwer points out that many participants were economically-secure

(c) 2021 The Author(s), under exclusive licence to Springer Nature Limited. 1470-8914 Contemporary S73 Political Theory Vol. 21, S2, S71-S75 
members of the middle class. He thus compares the January 6th insurrectionists to Reconstruction-era paramilitary groups of elite southern whites who violently assaulted the rule of law in order to maintain socioeconomic hegemony in the region (Serwer, 2021). Right-wing insurrection in the United States has often been waged by the bourgeoisie itself. For instance, in 1949, a fascist mob attacked Jewish-American and African-American families attending a concert by progressive singer and activist Paul Robeson in Peekskill, New York. Driven by anticommunist, antisemitic, and white supremacist motives, the mob assaulted the attendees while police stood by. Howard Fast, who was there and participated in the attendees' defense, wrote of the mob that 'they were not lumpen ... Most of them were prosperous-appearing men, well set up, well dressed'. Their ranks included “"decent" citizens', 'pillars of the local Catholic Church', and 'college students home on vacation' (1951, p. 24). Their political descendants, who stormed the Capitol in 2021, similarly were not bribed members of the underclass: of those arrested, only $9 \%$ were unemployed, and around $40 \%$ were professionals or business owners (Pape and Ruby, 2021).

In the United States, then, the proclivity of the bourgeoisie and petty bourgeoisie - for whom 'identity politics' have always been organically constitutive of their class position and power - to violent political reaction might legitimate thinking new possibilities for the organization of the lumpenproletariat, whose economic disenfranchisement and organization under anti-hegemonic formations of identitybased politics might well yield revolutionary gains. Barrow provides resources for thinking windows of political possibility that might open when the economically dislocated are considered in the particular social and ideological contexts of the United States. His achievement is to make the lumpenproletariat signify a Marxist problematic for thinking the challenges of class struggle in a historical moment when class composition and attendant political interests seem especially fluid.

\section{References}

Bussard, R. (1987) The 'Dangerous Class' of Marx and Engels: The rise of the idea of the lumpenproletariat. History of European Ideas 8(6): 675-692.

Draper, H. (1972) The concept of the 'Lumpenproletariat' in Marx and Engels. Économies et Sociétés 6(12): 2285-2312.

Fast, H. (1951) Peekskill, USA: Inside the Infamous 1949 Riots. Mineola, NY: Dover Publications.

Hardt, M. and A. Negri. (2004) Multitude: War and Democracy in the Age of Empire. New York: Penguin.

Marx, K. (1977) Capital: A Critique of Political Economy, Vol. 1. New York: Vintage.

Marx, K. (1963) The Eighteenth Brumaire of Louis Bonaparte. New York: International Publishers.

Mills, N. (2017) Ragged Revolutionaries: The Lumpenproletariat and African American Marxism in Depression-Era Literature. Amherst, MA: University of Massachusetts Press.

Pape, R. and K. Ruby. (2021) The Face of American Insurrection: Right-Wing Organizations Evolving into a Violent Mass Movement. Chicago Project on Security and Threats, February 25. https://

S74 (C) 2021 The Author(s), under exclusive licence to Springer Nature Limited. 1470-8914 Contemporary Political Theory Vol. 21, S2, S71-S75 
d3qi0qp55mx5f5.cloudfront.net/cpost/i/docs/americas_insurrectionists_online_2021_02_26. pdf?mtime $=1614612718$.

Serwer, A. (2021) The Capitol Rioters Weren't 'Low Class'. The Atlantic, 12 January. https://www. theatlantic.com/ideas/archive/2021/01/thoroughly-respectable-rioters/617644/.

Stallybrass, P. (1990) Marx and heterogeneity: Thinking the lumpenproletariat. Representations 31: 69-95.

Publisher's Note Springer Nature remains neutral with regard to jurisdictional claims in published maps and institutional affiliations.

Nathaniel Mills

University of Minnesota-Twin Cities, Minneapolis, MN 55455, USA mills175@umn.edu 